\title{
The interplay of DAMPs, TLR4, and proinflammatory cytokines in pulmonary fibrosis
}

\author{
Siavash Bolourani ${ }^{1,2,3} \cdot$ Max Brenner ${ }^{1,2,4}$ (D) Ping Wang ${ }^{1,2,3,4}$
}

Received: 13 January 2021 / Revised: 29 June 2021 / Accepted: 5 July 2021 / Published online: 13 July 2021

(c) The Author(s) 2021

\begin{abstract}
Pulmonary fibrosis is a chronic debilitating condition characterized by progressive deposition of connective tissue, leading to a steady restriction of lung elasticity, a decline in lung function, and a median survival of 4.5 years. The leading causes of pulmonary fibrosis are inhalation of foreign particles (such as silicosis and pneumoconiosis), infections (such as post COVID-19), autoimmune diseases (such as systemic autoimmune diseases of the connective tissue), and idiopathic pulmonary fibrosis. The therapeutics currently available for pulmonary fibrosis only modestly slow the progression of the disease. This review is centered on the interplay of damage-associated molecular pattern (DAMP) molecules, Toll-like receptor 4 (TLR4), and inflammatory cytokines (such as TNF- $\alpha$, IL-1 $\beta$, and IL-17) as they contribute to the pathogenesis of pulmonary fibrosis, and the possible avenues to develop effective therapeutics that disrupt this interplay.
\end{abstract}

Keywords DAMP · TLR4 · Cytokine · Pulmonary fibrosis

\section{Introduction}

Pulmonary fibrosis is a chronic restrictive lung disease characterized by a progressive decline in lung volume capacity, resulting from many chronic inflammatory disorders affecting the lung [1-3]. The visibility of pulmonary fibrosis, in particular, has significantly increased during the 2020 COVID-19 pandemic [4, 5]. Most hospitalized patients with COVID-19 have bilateral interstitial pneumonitis, as indicated by ground-glass opacities [6], and many show signs of fibrosis with their lung capacity reduced by up to $30 \%$ [7,

Max Brenner and Ping Wang contributed equally to this work.

Max Brenner

mbrenner@northwell.edu

$\triangle$ Ping Wang

pwang@northwell.edu

1 Center for Immunology and Inflammation, Feinstein Institutes for Medical Research, 350 Community Dr, Manhasset, NY 11030, USA

2 Elmezzi Graduate School of Molecular Medicine, Manhasset, NY, USA

3 Department of Surgery, Donald and Barbara Zucker School of Medicine At Hofstra/Northwell, Manhasset, NY, USA

4 Department of Molecular Medicine, Donald and Barbara Zucker School of Medicine At Hofstra/Northwell, Manhasset, NY, USA
8]. In addition to infections such as COVID-19, pulmonary fibrosis can also occur in the contexts of repeated inhalation of foreign particles (such as silicosis and pneumoconiosis) and autoimmune diseases (such as systemic autoimmune diseases of the connective tissue) $[9,10]$. The prototypical form of chronic fibrotic condition of the lung, however, is idiopathic pulmonary fibrosis (IPF), for which only pirfenidone (Esbriet, Genentech) [11] and nintedanib (Ofev, Boehringer Ingelheim) [12] have been FDA-approved to attenuate the rate of disease progression. IPF's median survival from diagnosis is 4.5 years [13], underlining the urgent medical need for more effective therapeutic approaches. Multiple genomewide association studies (GWAS) have reported genetic association signals in patients with IPF, stressing the importance of host defense, cell-cell adhesions, and DNA repair in the pathogenesis of the disease [14-18]. Furthermore, the altered host defense mechanisms explain not only the possible triggering of pulmonary fibrosis by chronic inflammation and viral infection but also the susceptibility of pulmonary fibrosis patients to viral-induced exacerbations [19].

During the past 10 years, damage-associated molecular pattern (DAMP) molecules have been shown to play a vital role in promoting exacerbation, remodeling, and silent progression of pulmonary fibrosis [20]. Toll-like receptors (TLRs), by virtue of being pattern recognition receptors of DAMPs, have been identified as critical mediators through which DAMPs exert their effect in 
cellular microenvironments. It is now clear that inflammation, though not the only trigger of fibrosis, plays a key role in the activation of fibroblasts - a cellular process critical in the development of pulmonary fibrosis. The pathogenetic model that we present in this review focuses on how DAMP signaling at the cellular level tilts the scale from remodeling and fibrosis resolution towards self-perpetuating cycles of connective tissue deposition leading to clinically relevant fibrosis.

\section{DAMPs and TLR4 in pulmonary fibrosis}

Intermittent episodes of transient inflammation in the lungs triggered by pathogens, chemical irritants, or autoimmunity can result in the necrosis and apoptosis of the epithelial cells and cause the release of intracellular components that act as DAMPs. The released DAMPs then activate homeostatic processes that most often promote the resolution of the insult underlying the inflammatory process. However, during more prolonged pathological states, this process is exaggerated, turning the homeostatic pulmonary environment into a self-perpetuating cycle of inflammation and DAMP release, resulting in pulmonary fibrosis.

Multiple structurally diverse DAMPs have been identified to act as mediators for this vicious cycle [20]. These include intracellular peptides [21], glycoproteins [22, 23], phospholipids [24], and even nucleic acids [25, 26] that are released to the environment during cell injury and necrosis processes which drive progressive tissue fibrosis. Once released, these endogenous ligands exert their effect mainly through TLRs [22]. TLRs are pattern recognition receptors to which DAMPs bind and, with the help of adaptor proteins, activate intracellular signal transduction cascades eliciting changes in gene expression and altering various cellular activities. Here, we focus on the profibrotic role of TLR4.

Among the TLRs, TLR4 has been shown to have a profibrotic effect in the lung when stimulated by DAMPs [27]. The first series of publications that illuminated the role of the TLR4 pathway on fibroblasts showed the activation of TLR4 enhances the process of fibrosis in the liver by downregulation the transforming growth factor (TGF)- $\beta$ pseudoreceptor Bambi through TLR4 $\rightarrow$ MyD88 $\rightarrow$ NF- $\kappa$ B pathway, which causes sensitization of hepatic stellate cells (HSCs) to TGF- $\beta 1$-induced signals and allows unrestricted activation of HSCs and differentiation to extracellular matrix (ECM)-producing myofibroblasts [28]. In this pioneering work, TLR4 was stimulated using lipopolysaccharide (LPS), a well-known and highly sensitive TLR4 activator [29-31]. Almost 11 years later, a similar effect was observed in persistent fibrosis of the lung through TLR4/myeloid differentiation 2 (MD2) complex related pathways and activation of pulmonary fibroblasts to myofibroblasts [32]. The stimulatory molecules used by Bhattacharyya et al. were tenascin-C (a multifunctional hexameric ECM protein) and fibronectin-extra domain A (Fn-EDA), which are potent TLR4 agonists generated within the injured pulmonary extracellular microenvironments [33-37]. The role of TLR4-activating DAMPs in pulmonary fibrosis has been further evaluated with high-mobility group box 1 (HMGB1), a potent inducer of TLR4 [38] in pulmonary fibrosis. HMGB1 is highly expressed in IPF lungs, and its blockade with antibodies attenuates bleomycin-induced fibrosis [39]. Along the same line is the small heat shock protein alphaB-crystallin (HSPB5), implicated in the TLR4-dependent induction and progression of pulmonary fibrosis [40, 41]. Mice deficient in HSPB5 had an attenuated response to bleomycin-induced pulmonary fibrosis [42]. Another category of TLR4 agonists that have recently been identified to be involved in the progression of pulmonary fibrosis consists of S100 proteins. Higher levels of S100A4 have been shown to independently correlate with worse disease progression in IPF [43], and S100A4 has been shown to contribute to fibrosis by activating pulmonary fibroblasts [44] (Table 1).

The induction of DAMPs following tissue injury or cell death in chronic inflammatory diseases has been studied extensively [45]. Oxidative stress and ECM matrix stiffness can also damage the microenvironment and contribute to the cycle of sustained fibrosis by the release of DAMPs [46]. However, support for whether this induction happens by direct effects on macrophages or fibroblasts to release DAMPs in the microenvironment is still lacking. Although some studies have suggested HMGB1 can be
Table 1 TLR4 stimulating DAMPs described in this review, their size, functionality, and primary location

\begin{tabular}{llll}
\hline Name & Size & Functionality & Primary location \\
\hline HMGB1 & 215 amino acids & Chromatin-binding & Nucleus \\
S100A4 & 121 amino acids & Calcium-binding & Nucleus/cytoplasm \\
HSPB5 & 44 amino acids & Protein chaperone & Nucleus \\
CIRP & 192 amino acids & RNA-binding & Nucleus \\
Fn-EDA & $500 \mathrm{kDa}$ glycoprotein & Collagen-binding & Extracellular matrix \\
Tenascin-C & $2,000 \mathrm{kDa}$ glycoprotein & Cell-cell signaling & Extracellular matrix \\
\hline
\end{tabular}


induced by reactive oxygen species (ROS) in macrophage and fibroblasts $[47,48]$, there is no evidence that HSPB5 protein can be induced by ROS in macrophages [49]. Furthermore, there is no conclusive evidence on whether the direct effect of ROS induces any profibrotic DAMPs in macrophages or fibroblasts in the fibrotic microenvironment. While Fn-EDA and tenascin-C are extracellular DAMPs contributing to ECM stiffness implicated in pulmonary fibrosis $[35,50]$, we know of no study that investigated the relationship between ECM stiffness and induction of profibrotic DAMPs at the cellular level in macrophages or fibroblasts.

\section{Inflammatory cytokines and pulmonary fibrosis}

Cytokines are proteins involved in cell signaling, including interferons, interleukins, tumor necrosis factors, and chemokines. Over the past 10 years, much evidence has been accumulated in the role of proinflammatory cytokines in fibrogenesis and myofibroblast differentiation [51, 52]. Cytokines that did not use to be part of the discussion in pulmonary fibrosis have recently been shown to be integral to several pathways that drive pulmonary fibrosis [53-57]. The overarching mechanisms by which proinflammatory cytokines tip the scale towards fibrogenesis include the recruitment of immune cells, regulation of the fibroblast activation status, and production of other profibrotic cytokines, among which is TGF- $\beta 1$, the master regulator of fibrosis.

Proinflammatory cytokines can be regulated in pulmonary fibrosis by oxidation stress and redox signaling through induction of mitochondria-derived ROS [58-60], NADPH oxidase (NOX) [61-65], and antioxidant depletion [60, 66-68]. They can also be regulated by ECM matrix stiffness through deposition of collagen [69] and cross-linking 2248755689 with fibronectin [70] in the fibrotic tissue microenvironment. As discussed later, evidence shows that these cytokines can also be induced by DAMP stimulation of macrophages and fibroblasts. Regardless of how they are induced, proinflammatory cytokines have shown to be a profibrotic player in the early phase of fibrosis [51]. At the cellular level, these cytokines exert their effect by three mechanisms: directly inducing fibroblast activation, causing the release of profibrotic cytokines (including TGF- $\beta 1$ ) in immune cells/fibroblasts, or promoting the persistent autocrine/paracrine activation of fibroblasts. Among the most studied proinflammatory and profibrotic cytokines is tumor necrosis factor-alpha (TNF- $\alpha$ ), interleukin (IL)- $1 \beta$, and IL-17.

\section{TNF-a}

In the case of TNF- $\alpha$, all three cellular mechanisms of fibrosis have been described [71-75]. The profibrotic effect of TNF- $\alpha$ can be seen in the lungs of patients with IPF expressing high levels of TNF- $\alpha$ [76]. TNF- $\alpha$ released from M1 macrophages (classically activated macrophages, involved in secretion of proinflammatory cytokines) not only changes the phenotype of other macrophages and fibroblasts from reparative to inflammatory and delay tissue repair $[77,78]$ but also induces the release of TGF- $\beta 1$ and platelet-derived growth factor (PDGF) from fibroblasts which in turn mediate fibroblast activation and production $[79,80]$. Furthermore, even quiescent fibroblasts, which are resistant to activation by TLR agonists, will respond to TNF- $\alpha[81,82]$. TNF- $\alpha$ stimulated fibroblasts to secrete lumican and express integrins that promote persistent activation of fibroblast in an autocrine and paracrine fashion [83-85]. Less is known, however, about the release of TNF- $\alpha$ in the fibrotic microenvironment. ROS intermediates regulate the release of TNF- $\alpha$ from macrophages and fibroblasts [86], and NOX generated ROS participate in TNF- $\alpha$-induced expression of vascular cell adhesion molecule 1 (VCAM-1) [87], which is a cell adhesion molecule highly expressed in the lungs of IPF patients [88] that is required for fibroblast activation [89]. The role of ECM stiffness in the release of TNF- $\alpha$ in a cellular fibrotic microenvironment is less clear. ECM stiffness has been shown to increase the release of TNF- $\alpha$ from RAW 264.7 murine macrophages [90]. However, the release of TNF- $\alpha$ was inversely proportional to ECM stiffness in THP-1 human macrophages [91]. Further studies are required to determine the effect of ECM stiffness and TNF- $\alpha$ release in the fibrotic pulmonary microenvironment.

\section{IL-17}

Like TNF- $\alpha$, IL-17 has been shown to play an important role in pulmonary fibrosis. Higher levels of IL-17 are found in lung tissues of IPF patients [92]. The mechanisms by which IL-17 is involved in the induction of fibrosis are likely very similar to those of TNF- $\alpha$ [93-95]. Furthermore, TNF- $\alpha$ and IL-17 have been shown to be the leading players in the recruitment of immune cells in the early stages of fibrosis [96]. The combination of these effects means that, overall, TNF- $\alpha$ and IL-17 are involved in sustained and intense activation of fibroblasts [97]. However, evidence has emerged that the effects of IL-17 on pulmonary fibrosis may be temporally distinct from those of TNF- $\alpha$. While IL- 17 has been shown to enhance the proliferation of fibroblasts [98], collagen deposition does not increase in the presence of IL-17 
[99], and in fact, the signaling pathway of IL-17 is downregulated during collagen deposition [100]. Nevertheless, the precise role of IL-17 in fibroblast activation remains to be elucidated. The role of oxidative stress in the production of IL-17 has also remained unclear. While ROS induce TNF- $\alpha$ expression in macrophages and fibroblasts $[87,101]$ and aid IL-17 induced proliferation of fibroblasts [102], they have not been shown to increase the expression of IL-17 directly. Furthermore, to our knowledge, no study has yet shown the correlation between ECM stiffness and IL-17 expression on macrophages.

\section{IL-1 $\beta$}

The profibrotic role of IL- $1 \beta$ has long been known: mice overexpressing IL-1 $\beta$ have an exacerbated response to bleomycin-induced lung fibrosis [103]. Like TNF- $\alpha$, $\mathrm{IL}-1 \beta$ is a potent proinflammatory cytokine that induces activation of fibroblasts via the release of profibrotic cytokines like TGF- $\beta 1$ [104]. Multiple pathways have been studied in connection with the direct effect of IL- $1 \beta$ on fibroblast activation [105-107]. Some studies have suggested that IL- $1 \beta$ is a cytokine upstream of IL-17 or that the profibrotic effect of IL- $1 \beta$ is contingent on IL-17 [108-110]. Other studies have indicated that the profibrotic effects of IL- $1 \beta$ are mediated through the IL-1 receptor 1 (IL-1R1)/myeloid differentiation primary response 88 (MyD88) pathway [111, 112]. Further studies are needed to elucidate the exact mechanism by which IL-1 $\beta$ tilts the immune cells and fibroblasts towards persistent fibrosis in the lung microenvironment.

\section{Connecting DAMPs, TLR4, and proinflammatory cytokines}

In the previous sections, we reviewed the profibrotic effects of individual DAMPs and proinflammatory cytokines in the development of fibrosis. However, it should be noted that the interplay between DAMPs and cytokines exerts a critical role in the development and sustainment of fibrosis. The interaction between DAMPs and TLR4 causes the release of numerous proinflammatory cytokines on macrophages and fibroblasts [113, 114]. These cytokines can, in turn, activate other macrophages and fibroblasts, as described in the previous section. This interplay has been demonstrated by induction of TNF- $\alpha$ and IL- $1 \beta$ expression in fibroblasts by activating the TLR4 pathway [115] using LPS. HMGB1 has also been shown to induce TNF- $\alpha$ and IL- $1 \beta$ signaling in macrophages through the TLR4-dependent pathway [85, 116, 117]. Similarly, HSPB5 has been shown to increase IL-1 $\beta$ and the nuclear localization of Smad4 [42, 118], which is likely enhanced by TLR4 signaling [118].
One built-in defense mechanism against the development of pathological fibrosis is the induction of negative feedback loops by cytokines and DAMPs. TGF- $\beta 1$ and IL-10 released by inflammatory macrophages and fibroblasts, for example, are potent inhibitors of inflammation in macrophages and fibroblasts which can tilt the organ towards resolution of fibrosis [119-121] in the late phase of fibrosis [122]. Furthermore, DAMPs can be protective against or involved in the resolution of fibrosis in some TLR signaling pathways. While fibroblast-specific deficiency of TLR4 has been shown to be protective against fibrosis, and TLR2 has shown to exacerbate bleomycininduced pulmonary fibrosis by inducing an oxidative response [123-125], mice deficient in both TLR4 and TLR2 have been shown to have increased pulmonary fibrosis in response to radiation injury [126-128]. There are also antifibrotic TLRs that contrast the effect of DAMPs on profibrotic TLRs $[22,129]$. TLR3 has been shown to have an antifibrotic effect by downregulation of the TGF$\beta 1$ signaling pathway and autocrine induction of interferon (IFN)- $\beta$ [130-132]. Moreover, TLR3 deficiency in fibroblasts has also been shown to increase collagen deposition and profibrotic cytokines, suggesting the role of DAMPs through TLR3 in the resolution of fibrosis [133]. Similarly, TLR9-mediated IFN- $\beta$ induction in fibroblasts has shown to be protective against pulmonary fibrosis, and TLR9deficient mice have exacerbated pulmonary fibrosis [134].

When taken together, a picture emerges that juxtaposes the interaction of DAMPs and cytokines through TLR4 promoting persistent fibrosis and, through other TLRs, the resolution of fibrosis. The pathology ensues when the balance is tilted towards the persistent profibrotic pathway by different sections of the pathway perpetuated through positive feedback. This has therapeutic potential in fibrotic diseases of the lung not only by disrupting TLR4 pathways and DAMPs but also by inducing antifibrotic TLRs.

\section{Therapeutic considerations}

While the research in therapeutic approaches to pulmonary fibrosis is ongoing, treatment strategies targeting the DAMPs, TLR4, and proinflammatory cytokines pathway have shown promising results in preclinical models (Table 2). Anti-HMGB1 antibody significantly attenuated lung fibrosis in a mouse model [39]. In addition, there is evidence that inhibition of HMGB1 will diminish fibroblast activation [135] and can disrupt the process of fibrosis [136]. Furthermore, silencing HMGB1 or its downstream signaling has proven successful in inhibiting the fibrotic process in different conditions $[137,138]$. Anti-S100A4 has been shown to prevent bleomycin-induced pulmonary fibrosis in mice [44]. While the effect of anti-HSPB5 antibody in pulmonary 
Table 2 Potential molecular targets, therapeutic, and the stage of investigation for the interplay described in this review

\begin{tabular}{|c|c|c|c|}
\hline Molecular target & Potential therapeutic & Stage of investigation & References \\
\hline HMGB1 & Anti-HMGB1 antibody & Mouse models have shown attenuated response to fibrosis & {$[39,136-138]$} \\
\hline S100A4 & Anti-S100A4 antibody: 3B11* & Mouse models have shown attenuated response to fibrosis & {$[42,44]$} \\
\hline HSPB5 & Anti-HSPB5 antibody & HSPB5-deficient mice have attenuated fibrotic response & {$[42,44]$} \\
\hline Tenascin-C & Anti-tenascin-C antibody: ST2485 ${ }^{*}$ & $\begin{array}{l}\text { Mouse models have shown attenuated response to fibrosis, } \\
\text { and the process is TLR } 4 \text { dependent }\end{array}$ & [33-35] \\
\hline TLR4/MD2 & Anti-TLR4/MD2 complex antibody: T5342126 & Mouse models have shown attenuated response to fibrosis & {$[32-35]$} \\
\hline TNF- $\alpha$ & Anti-TNF- $\alpha$ antibody: etanercept & $\begin{array}{l}\text { Two double-blind randomized control trials have shown } \\
\text { reduced disease progression }\end{array}$ & {$[11,140-145]$} \\
\hline IL-1 $\beta$ & Anti-IL-1 $\beta$ antibody: canakinumab ${ }^{*}$ & $\begin{array}{l}\text { IL-1R } 1 \text { deficiency in mice and monoclonal antibody has } \\
\text { been shown to attenuate fibrosis in mice }\end{array}$ & {$[111,146]$} \\
\hline IL-17 & $\begin{array}{l}\text { Anti-IL-17 antibody: secukinumab", } \\
\text { brodalumab*, and ixekizumab* }\end{array}$ & Mouse models have shown attenuated response to fibrosis & {$[93,147]$} \\
\hline
\end{tabular}

*These agents have not yet been studied in the context of fibrosis

fibrosis has not been studied, HSPB5-deficient mice have attenuated pulmonary fibrosis in response to bleomycin [42]. Among the extracellular TLR4 agonists present in the pulmonary fibrotic microenvironment, neutralizing tenascin-C is a promising target for antifibrotic therapy. Not only do tenascin-C-deficient mice have an attenuated response to bleomycin-induced lung fibrosis, but this process has also been shown to be TLR4 dependent [35].

While studies have looked at the effect of anti-TLR4 in stopping pulmonary fibrosis, many have failed. This is due to the fact that while TLR4 drives persistent fibrosis and fibroblast activation, TLR4 is also required for the resolution of fibrosis [139]. However, there is a promise that specifically targeting specific TLR4/MD2 signaling complexes, which are responsible for the profibrotic effect of TLR4, can provide potential therapeutic strategies $[32,35]$.

Anti-TNF- $\alpha$ antibodies embody the most successful therapeutic approaches to fibrotic lung diseases. While multiple studies have shown the therapeutic effects in animal models [140-142], a double-blind clinical trial of IPF patients treated with etanercept, a monoclonal antibody against TNF- $\alpha$, improved neither the forced vital capacity nor the diffusing capacity of the lungs. However, it showed a non-significant improvement in function and quality of life measures [143]. The multicentric double-blind clinical trial "A Study of Cardiovascular Events in Diabetes" (ASCEND) showed that pirfenidone, a non-peptide synthetic molecule with anti-TNF- $\alpha$ activity, reduced disease progression in patients with IPF [11]. Additionally, a study combining the results of two previous trials of pirfenidone in IPF patients [144] observed a significant decrease in the risk of death after treatment [145]. While there has not been a trial evaluating the effect of neutralizing IL- $1 \beta$ in IPF, mice deficient in IL-1R1 are protected and developed attenuated bleomycin-induced pulmonary fibrosis [111]. Moreover, a monoclonal anti-IL-1 $\beta$ antibody has also been shown to attenuate silica-induced fibrosis in mice [146]. Along the same line, blocking IL-17 has shown to attenuate pulmonary fibrosis in both silica and bleomycin-induced pulmonary fibrosis models in mice and to promote resolution of fibrosis $[93,147]$.

\section{Conclusion and perspective}

Strong evidence has emerged that pulmonary fibrosis results from a cycle receiving positive feedback at multiple checkpoints that are instigated by DAMP induction of proinflammatory cytokines through TLR4 receptors. The process starts with an injury either from a viral infection, chemical/mechanical trauma, or immune-mediated damage that causes the release of DAMPs in the microenvironment (Fig. 1). The DAMPs then reprogram resident macrophages and fibroblasts towards a proinflammatory/ profibrotic phenotype in a TLR4-dependent process. This prompts the deposition of extracellular collagen leading to ECM stiffness and the further release of DAMPs and proinflammatory/profibrotic cytokines along with the secretion of TGF- $\beta 1$, the master regulator of fibrosis. TGF- $\beta 1$, in turn, causes autocrine/paracrine activation of other macrophages and fibroblasts in the microenvironment that feeds the vicious cycle of persistent fibrosis. In our not yet published observations, we have discovered that extracellular cold-inducible RNA-binding protein (eCIRP), a DAMP that causes inflammation and organ injury in sepsis, hemorrhagic shock, and ischemia/reperfusion injury [148, 149], also plays an important role in the pathogenesis of pulmonary fibrosis. By targeting eCIRP, we may be able to ameliorate the fibrotic process in the lungs.

In this review, we have focused on a selected number of inflammatory cytokines, namely TNF- $\alpha$, IL- $1 \beta$, and IL-17, and showed the interplay of TLR4, DAMPs, and 


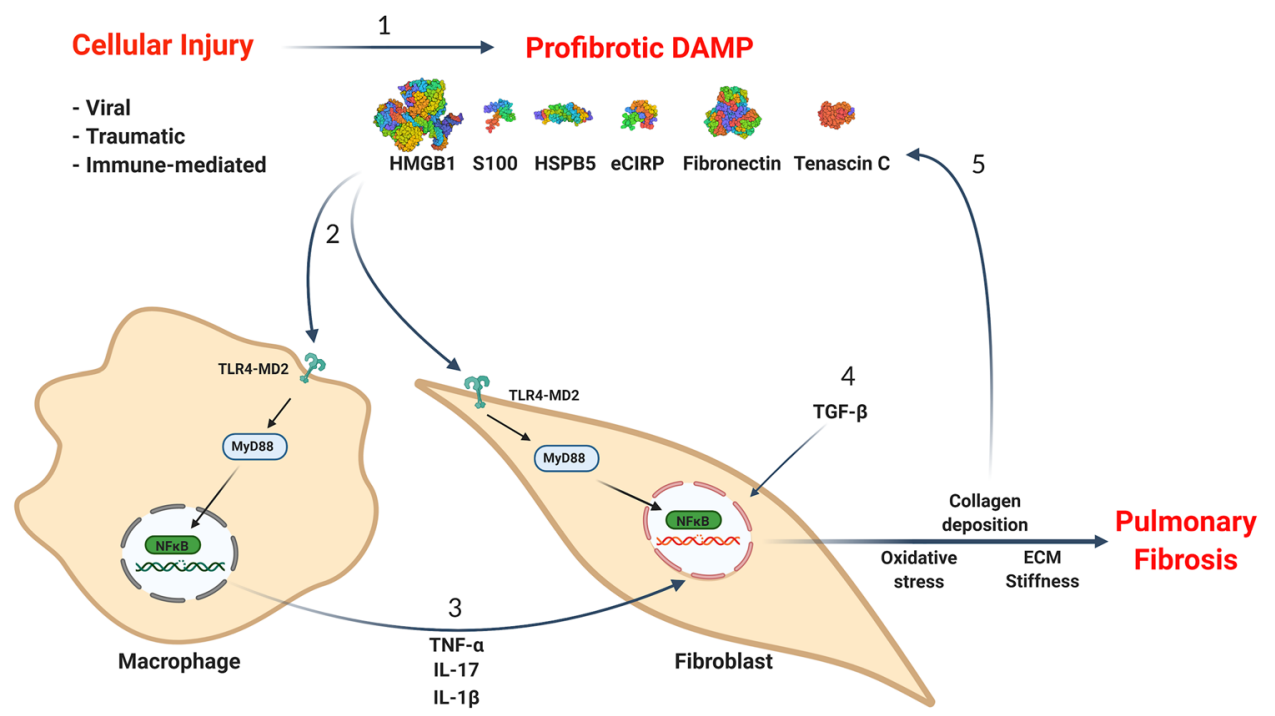

Fig. 1 The interplay of DAMPs, TLR4, and proinflammatory cytokines in pulmonary fibrosis centered around macrophages and fibroblasts. (1) Injury to the cells either from a viral infection, chemical/mechanical trauma, or immune-mediated damage causes the release of DAMPs in the microenvironment. (2) DAMPs stimulate and activate macrophages and fibroblasts through a TLR4MD2 $\rightarrow$ MyD88-mediated pathway. (3) Activated macrophages release proinflammatory cytokines such as TNF- $\alpha$, IL-17, and IL-1 $\beta$ in the tissue microenvironment that, (4) along with TGF- $\beta$, activate fibroblasts to become profibrotic and deposit collagen and ECM com- ponents like fibronectin and tenascin-C. This causes stiffness of ECM and oxidative stress in the microenvironment, which (5) causes the release of more DAMPs leading to the vicious cycle of pulmonary fibrosis. DAMP, damage-associated molecular patterns; HMGB1, high-mobility group box 1; eCIRP, extracellular cold-inducible RNAbinding protein; HSPB5, heat shock protein B5; TLR4, Toll-likereceptor 4; MD2, myeloid differentiation factor 2; MyD88, myeloid differentiation primary response 88 ; NF- $\kappa \mathrm{B}$, nuclear factor kappalight-chain-enhancer of activated B cells; ECM, extracellular matrix

Additionally, we focused on the fibrotic effect of TLR4 in the early phases of fibrosis in this review. However, as mentioned earlier in the review, TLR4 also plays a crucial role in the resolution of fibrosis in later phases of fibrosis and remodeling [139]. TLR $4^{-/}$mice are more susceptible to intratracheal bleomycin-induced lung fibrosis due to (1) impaired type 2 alveolar epithelial cells renewal, which are critical cells in the fibrosis repair process [162], and (2) impaired activation of autophagy signaling leading to accumulation of ROS [139].

Although we focused on macrophages and their interactions with fibroblasts in this review, a wide range of immune cell types are also involved in the progression and resolution of fibrosis [163]. Neutrophils are the cells that are recruited early stages of the fibrotic process, mice depleted from neutrophils have ameliorated response to, and the failure in recruiting neutrophils protects mice from bleomycininduced pulmonary fibrosis $[164,165]$. On the other hand, natural killer cells may have a protective effect against lung fibrosis [166]. Without NK cell recruitment, the pulmonary environment lacks IFN- $\gamma$, an important anti-inflammatory cytokine involved in the resolution of fibrosis [167]. This results in an enhanced fibrosis process in the lung [168, 169]. Dendritic cells (DCs), however, may play a dual role in pulmonary fibrosis. Like neutrophils, DCs arrive in the 
early phases of pulmonary fibrosis in significant numbers, and inhibiting the immune activity of DCs attenuates fibrosis [170]. However, it has also been observed that mice deficient in DCs develop more severe fibrosis, and, in contrast, mice equipped with an increasing number of DCs develop milder pulmonary fibrosis after the bleomycin challenge [171]. The mechanisms by which DCs exert their pro/antifibrotic role remain to be further elucidated [172]. We believe macrophages are the most pertinent to this review because they are the master regulator of fibrosis across organs, given that they are the primary providers of TGF- $\beta$ [173]. Additionally, the close interaction of macrophages with fibroblasts is a critical contributor to the cycle described in this review $[174,175]$.

In this review, we summarized the current state of knowledge regarding the role of DAMPs, selected proinflammatory cytokines, their interplay through TLRs (more specifically TLR4), and their contribution to cellular processes of lung fibrosis. Furthermore, we highlighted knowledge gaps and summarized the therapeutic potential of targeting this vicious fibrotic cycle at every checkpoint. Given that the issue of persistent fibrosis without resolution in COVID-19, IPF, and other profibrotic lung diseases is far from resolved, it is critical to look deeper into these pathways to illuminate not only the connection between the inflammatory reaction and fibrosis but also develop possible therapeutics that can ameliorate pulmonary fibrosis by disrupting the positive feedback pathways involved.

Author contribution SB and MB wrote the manuscript and prepared the figures. MB and PW revised and edited the manuscript. PW conceived the original idea of this review. All authors read and approved the final manuscript.

Funding This study was supported by the National Institutes of Health (NIH) grants R01HL076179 (PW) and R35GM118337 (PW).

\section{Declarations}

Ethics approval This research has full compliance with ethical standards as pertinent to this review article.

Consent for publication Not applicable.

Competing interests The authors declare no competing interests.

Open Access This article is licensed under a Creative Commons Attribution 4.0 International License, which permits use, sharing, adaptation, distribution and reproduction in any medium or format, as long as you give appropriate credit to the original author(s) and the source, provide a link to the Creative Commons licence, and indicate if changes were made. The images or other third party material in this article are included in the article's Creative Commons licence, unless indicated otherwise in a credit line to the material. If material is not included in the article's Creative Commons licence and your intended use is not permitted by statutory regulation or exceeds the permitted use, you will need to obtain permission directly from the copyright holder. To view a copy of this licence, visit http://creativecommons.org/licenses/by/4.0/.

\section{References}

1. Kaminski N, Allard JD, Pittet JF, Zuo F, Griffiths MJ, Morris D, Huang X, Sheppard D, Heller RA (2000) Global analysis of gene expression in pulmonary fibrosis reveals distinct programs regulating lung inflammation and fibrosis. Proc Natl Acad Sci USA 97:1778-1783

2. Gifford AH, Matsuoka M, Ghoda LY, Homer RJ, Enelow RI (2012) Chronic inflammation and lung fibrosis: pleotropic syndromes but limited distinct phenotypes. Mucosal Immunol 5:480-484

3. Bringardner BD, Baran CP, Eubank TD, Marsh CB (2008) The role of inflammation in the pathogenesis of idiopathic pulmonary fibrosis. Antioxid Redox Signal 10:287-302

4. Srivastava M (2020) Israel to enter lockdown again as second wave of Covid-19 surges. In: Financial Times. https://www. ft.com/content/79f8323b-6cf8-48ca-9118-bdc764756fef. Accessed 15 Oct 2020

5. Landler M (2020) Europe which thought it had coronavirus tamed faces second wave. The New York Times, New York

6. Wang D, Hu B, Hu C, Zhu F, Liu X, Zhang J, Wang B, Xiang $\mathrm{H}$, Cheng Z, Xiong Y et al (2020) Clinical characteristics of 138 hospitalized patients with 2019 novel coronavirus-infected pneumonia in Wuhan. China JAMA 323:1061

7. Fraser E (2020) Long term respiratory complications of Covid19. BMJ 370:m3001

8. Manfredi A, Luppi F, Cassone G, Vacchi C, Salvarani C, Sebastiani M (2020) Pathogenesis and treatment of idiopathic and rheumatoid arthritis-related interstitial pneumonia. The possible lesson from COVID-19 pneumonia. Expert Rev Clin Immunol 16:751-770

9. Mossman BT, Churg A (1998) Mechanisms in the pathogenesis of asbestosis and silicosis. Am J Respir Crit Care Med 157:1666-1680

10. Cottin V (2013) Significance of connective tissue diseases features in pulmonary fibrosis. Eur Respir Rev 22:273-280

11. King TE Jr, Bradford WZ, Castro-Bernardini S, Fagan EA, Glaspole I, Glassberg MK, Gorina E, Hopkins PM, Kardatzke D, Lancaster L et al (2014) A phase 3 trial of pirfenidone in patients with idiopathic pulmonary fibrosis. N Engl J Med 371:1172-1172

12. Flaherty KR, Wells AU, Brown KK (2020) Nintedanib in progressive fibrosing interstitial lung diseases. N Engl J Med 382:781

13. Kaunisto J, Salomaa ER, Hodgson U, Kaarteenaho R, Kankaanranta H, Koli K, Vahlberg T, Myllärniemi M (2019) Demographics and survival of patients with idiopathic pulmonary fibrosis in the Finnish IPF registry. ERJ Open Res 5:00170-02018

14. Mushiroda T, Wattanapokayakit S, Takahashi A, Nukiwa T, Kudoh S, Ogura T, Taniguchi H, Kubo M, Kamatani N, Nakamura Y et al (2008) A genome-wide association study identifies an association of a common variant in TERT with susceptibility to idiopathic pulmonary fibrosis. J Med Genet 45:654-656

15. Noth I, Zhang Y, Ma SF, Flores C, Barber M, Huang Y, Broderick SM, Wade MS, Hysi P, Scuirba J et al (2013) Genetic variants associated with idiopathic pulmonary fibrosis susceptibility and mortality: a genome-wide association study. Lancet Respir Med 1:309-317 
16. Fingerlin TE, Murphy E, Zhang W, Peljto AL, Brown KK, Steele MP, Loyd JE, Cosgrove GP, Lynch D, Groshong S et al (2013) Genome-wide association study identifies multiple susceptibility loci for pulmonary fibrosis. Nat Genet 45:613-620

17. Fingerlin TE, Zhang W, Yang IV, Ainsworth HC, Russell PH, Blumhagen RZ, Schwarz MI, Brown KK, Steele MP, Loyd JE et al (2016) Genome-wide imputation study identifies novel HLA locus for pulmonary fibrosis and potential role for auto-immunity in fibrotic idiopathic interstitial pneumonia. BMC Genet 17:74

18. Allen RJ, Porte J, Braybrooke R, Flores C, Fingerlin TE, Oldham JM, Guillen-Guio B, Ma SF, Okamoto T, John AE et al (2017) Genetic variants associated with susceptibility to idiopathic pulmonary fibrosis in people of European ancestry: a genome-wide association study. Lancet Respir Med 5:869-880

19. Moore BB, Moore TA (2015) Viruses in idiopathic pulmonary fibrosis: Etiology and exacerbation. Ann Am Thorac Soc 12(2):186-192

20. Ellson CD, Dunmore R, Hogaboam CM, Sleeman MA, Murray LA (2014) Danger-associated molecular patterns and danger signals in idiopathic pulmonary fibrosis. Am J Respir Cell Mol Biol 51:163-168

21. Ge X, Arriazu E, Magdaleno F, Antoine DJ, Dela Cruz R, Theise N, Nieto N (2018) High mobility group box-1 drives fibrosis progression signaling via the receptor for advanced glycation end products in mice. Hepatology 68:2380-2404

22. Karampitsakos T, Woolard T, Bouros D, Tzouvelekis A (2017) Toll-like receptors in the pathogenesis of pulmonary fibrosis. Eur J Pharmacol 808:35-43

23. Schaefer L (2014) Proteoglycans, key regulators of cell-matrix dynamics. Matrix Biol 35:1-2

24. Cesta MF, Ryman-Rasmussen JP, Wallace DG, Masinde T, Hurlburt G, Taylor AJ, Bonner JC (2010) Bacterial lipopolysaccharide enhances PDGF signaling and pulmonary fibrosis in rats exposed to carbon nanotubes. Am J Respir Cell Mol Biol 43:142-151

25. Maeda A, Fadeel B (2014) Mitochondria released by cells undergoing TNF- $\alpha$-induced necroptosis act as danger signals. Cell Death Dis 5:e1312

26. Gu X, Wu G, Yao Y, Zeng J, Shi D, Lv T, Luo L, Song Y (2015) Intratracheal administration of mitochondrial DNA directly provokes lung inflammation through the TLR9-p38 MAPK pathway. Free Radic Biol Med 83:149-158

27. He Z, Zhu Y, Jiang H (2009) Inhibiting toll-like receptor 4 signaling ameliorates pulmonary fibrosis during acute lung injury induced by lipopolysaccharide: an experimental study. Respir Res 10:126

28. Seki E, De Minicis S, Österreicher CH, Kluwe J, Osawa Y, Brenner DA, Schwabe RF (2007) TLR4 enhances TGF- $\beta$ signaling and hepatic fibrosis. Nat Med 13:1324-1332

29. Paik Y (2003) Toll-like receptor 4 mediates inflammatory signaling by bacterial lipopolysaccharide in human hepatic stellate cells. Hepatology 37:1043-1055

30. Brun P, Castagliuolo I, Pinzani M, Palù G, Martines D (2005) Exposure to bacterial cell wall products triggers an inflammatory phenotype in hepatic stellate cells. Am J Physiol Gastrointest Liver Physiol 289:G571-G578

31. Mühlbauer M, Weiss TS, Thasler WE, Gelbmann CM, Schnabl B, Schölmerich J, Hellerbrand C (2004) LPS-mediated NFkap$\mathrm{paB}$ activation varies between activated human hepatic stellate cells from different donors. Biochem Biophys Res Commun 325:191-197

32. Bhattacharyya S, Wang W, Qin W, Cheng K, Coulup S, Chavez S, Jiang S, Raparia K, De Almeida LMV, Stehlik C et al (2018) TLR4-dependent fibroblast activation drives persistent organ fibrosis in skin and lung. JCI Insight 3:e98850
33. Bhattacharyya S, Kelley K, Melichian DS, Tamaki Z, Fang F, Su Y, Feng G, Pope RM, Budinger GRS, Mutlu GM et al (2013) Toll-like receptor 4 signaling augments transforming growth factor- $\beta$ responses: a novel mechanism for maintaining and amplifying fibrosis in scleroderma. Am J Pathol 182:192-205

34. Bhattacharyya S, Tamaki Z, Wang W, Hinchcliff M, Hoover P, Getsios S, White ES, Varga J (2014) FibronectinEDA promotes chronic cutaneous fibrosis through Toll-like receptor signaling. Sci Transl Med 6:232ra50

35. Bhattacharyya S, Wang W, Morales-Nebreda L, Feng G, Wu M, Zhou X, Lafyatis R, Lee J, Hinchcliff M, Feghali-Bostwick C et al (2016) Tenascin-C drives persistence of organ fibrosis. Nat Commun 7:11703

36. Midwood K, Sacre S, Piccinini AM, Inglis J, Trebaul A, Chan E, Drexler S, Sofat N, Kashiwagi M, Orend G et al (2009) Tenascin$\mathrm{C}$ is an endogenous activator of Toll-like receptor 4 that is essential for maintaining inflammation in arthritic joint disease. Nat Med 15:774-780

37. Okamura Y, Watari M, Jerud ES, Young DW, Ishizaka ST, Rose J, Chow JC, Strauss JF (2001) The extra domain A of fibronectin activates Toll-like receptor 4. J Biol Chem 276:10229-10233

38. Park JS, Svetkauskaite D, He Q, Kim JY, Strassheim D, Ishizaka A, Abraham E (2004) Involvement of toll-like receptors 2 and 4 in cellular activation by high mobility group box 1 protein. J Biol Chem 279:7370-7377

39. Hamada N, Maeyama T, Kawaguchi T, Yoshimi M, Fukumoto J, Yamada M, Yamada S, Kuwano K, Nakanishi Y (2008) The role of high mobility group box 1 in pulmonary fibrosis. Am J Respir Cell Mol Biol 39:440-447

40. Roelofs MF, Boelens WC, Joosten LAB, Abdollahi-Roodsaz S, Geurts J, Wunderink LU, Schreurs BW, van den Berg WB, Radstake TRDJ (2006) Identification of small heat shock protein B8 (HSP22) as a novel TLR4 ligand and potential involvement in the pathogenesis of rheumatoid arthritis. J Immunol 176:7021-7027

41. Rao NA, Saraswathy S, Pararajasegaram G, Bhat SP (2012) Small heat shock protein $\alpha \mathrm{A}$-crystallin prevents photoreceptor degeneration in experimental autoimmune uveitis. PLoS One 7:e33582

42. Bellaye PS, Wettstein G, Burgy O, Besnard V, Joannes A, Colas J, Causse S, Marchal-Somme J, Fabre A, Crestani B et al (2014) The small heat-shock protein $\alpha \mathrm{B}$-crystallin is essential for the nuclear localization of Smad4: impact on pulmonary fibrosis. J Pathol 232:458-472

43. Akiyama N, Hozumi H, Isayama T, Okada J, Sugiura K, Yasui H, Suzuki Y, Kono M, Karayama M, Furuhashi K et al (2020) Clinical significance of serum S100 calcium-binding protein A4 in idiopathic pulmonary fibrosis. Respirology 25:743-749

44. Li Y, Bao J, Bian Y, Erben U, Wang P, Song K, Liu S, Li Z, Gao Z, Qin Z (2018) S100A4 macrophages are necessary for pulmonary fibrosis by activating lung fibroblasts. Front Immunol 9:1776

45. Roh JS, Sohn DH (2018) Damage-associated molecular patterns in inflammatory diseases. Immune Netw 18:e27

46. Kliment CR, Oury TD (2010) Oxidative stress, extracellular matrix targets, and idiopathic pulmonary fibrosis. Free Radic Biol Med 49:707-717

47. Tang D, Shi Y, Kang R, Li T, Xiao W, Wang H, Xiao X (2007) Hydrogen peroxide stimulates macrophages and monocytes to actively release HMGB1. J Leukoc Biol 81:741-747

48. Tang D, Kang R, Livesey KM, Cheh CW, Farkas A, Loughran P, Hoppe G, Bianchi ME, Tracey KJ, Zeh HJ et al (2010) Endogenous HMGB1 regulates autophagy. J Cell Biol 190:881-892

49. van Noort JM, Bsibsi M, Gerritsen WH, van der Valk P, Bajramovic JJ, Steinman L, Amor S (2010) $\alpha \mathrm{B}$-Crystallin is a target for adaptive immune responses and a trigger of innate 
responses in preactive multiple sclerosis lesions. J Neuropathol Exp Neurol 69:694-703

50. Upagupta C, Shimbori C, Alsilmi R, Kolb M (2018) Matrix abnormalities in pulmonary fibrosis. Eur Respir Rev 27:180033

51. Borthwick LA, Wynn TA, Fisher AJ (2013) Cytokine mediated tissue fibrosis. Biochim Biophys Acta Mol Basis Dis 1832:1049-1060

52. Henderson NC, Rieder F, Wynn TA (2020) Fibrosis: from mechanisms to medicines. Nature 587:555-566

53. Singh B, Kasam RK, Sontake V, Wynn TA, Madala SK (2017) Repetitive intradermal bleomycin injections evoke T-helper cell 2 cytokine-driven pulmonary fibrosis. Am J Physiol Lung Cell Mol Physiol 313:L796-L806

54. Papiris SA, Tomos IP, Karakatsani A, Spathis A, Korbila I, Analitis A, Kolilekas L, Kagouridis K, Loukides S, Karakitsos $P$ et al (2018) High levels of IL-6 and IL-8 characterize earlyon idiopathic pulmonary fibrosis acute exacerbations. Cytokine 102:168-172

55. Xu Z, Yuan X, Gao Q, Li Y, Li M (2020) Interleukin-38 overexpression prevents bleomycin-induced mouse pulmonary fibrosis. Naunyn Schmiedebergs Arch Pharmacol. https://doi.org/10.1007/ s00210-020-01920-3

56. Kim YI, Shin HW, Chun YS, Cho CH, Koh J, Chung DH, Park JW (2018) Epithelial cell-derived cytokines CST3 and GDF15 as potential therapeutics for pulmonary fibrosis. Cell Death Dis 9:506

57. Xu L, Bian W, Gu XH, Shen C (2017) Differing expression of cytokines and tumor markers in combined pulmonary fibrosis and emphysema compared to emphysema and pulmonary fibrosis. COPD 14:245-250

58. Osborn-Heaford HL, Ryan AJ, Murthy S, Racila AM, He C, Sieren JC, Spitz DR, Carter AB (2012) Mitochondrial Rac1 GTPase import and electron transfer from cytochrome c are required for pulmonary fibrosis. J Biol Chem 287:3301-3312

59. He C, Murthy S, McCormick ML, Spitz DR, Ryan AJ, Carter AB (2011) Mitochondrial Cu, Zn-superoxide dismutase mediates pulmonary fibrosis by augmenting $\mathrm{H} 2 \mathrm{O} 2$ generation. J Biol Chem 286:15597-15607

60. Murthy S, Adamcakova-Dodd A, Perry SS, Tephly LA, Keller RM, Metwali N, Meyerholz DK, Wang Y, Glogauer M, Thorne PS et al (2009) Modulation of reactive oxygen species by Rac1 or catalase prevents asbestos-induced pulmonary fibrosis. Am J Physiol Lung Cell Mol Physiol 297:L846-L855

61. Hecker L, Vittal R, Jones T, Jagirdar R, Luckhardt TR, Horowitz JC, Pennathur S, Martinez FJ, Thannickal VJ (2009) NADPH oxidase-4 mediates myofibroblast activation and fibrogenic responses to lung injury. Nat Med 15:1077-1081

62. Crestani B, Besnard V, Boczkowski J (2011) Signalling pathways from NADPH oxidase-4 to idiopathic pulmonary fibrosis. Int J Biochem Cell Biol 43:1086-1089

63. Hecker L, Cheng J, Thannickal VJ (2012) Targeting NOX enzymes in pulmonary fibrosis. Cell Mol Life Sci 69:2365-2371

64. Manoury B, Nenan S, Leclerc O, Guenon I, Boichot E, Planquois J-M, Bertrand CP, Lagente V (2005) The absence of reactive oxygen species production protects mice against bleomycininduced pulmonary fibrosis. Respir Res 6:11

65. Cucoranu I, Clempus R, Dikalova A, Phelan PJ, Ariyan S, Dikalov S, Sorescu D (2005) NAD(P)H oxidase 4 mediates transforming growth factor-beta1-induced differentiation of cardiac fibroblasts into myofibroblasts. Circ Res 97:900-907

66. Hagiwara SI, Ishii Y, Kitamura S (2000) Aerosolized administration of $\mathrm{N}$-acetylcysteine attenuates lung fibrosis induced by bleomycin in mice. Am J Respir Crit Care Med 162:225-231

67. Borok Z, Buhl R, Grimes GJ, Bokser AD, Hubbard RC, Holroyd KJ, Roum JH, Czerski DB, Cantin AM, Crystal RG (1991) Effect of glutathione aerosol on oxidant-antioxidant imbalance in idiopathic pulmonary fibrosis. Lancet 338:215-216

68. Kinnula VL, Crapo JD (2003) Superoxide dismutases in the lung and human lung diseases. Am J Respir Crit Care Med 167:1600-1619

69. Aravinthan A, Park JK, Hossain MA, Sharmila J, Kim HJ, Kang CW, Kim NS, Kim JH (2018) Collagen-based sponge hastens wound healing via decrease of inflammatory cytokines. 3 Biotech $8: 487$

70. Clarke DL, Carruthers AM, Mustelin T, Murray LA (2013) Matrix regulation of idiopathic pulmonary fibrosis: the role of enzymes. Fibrogenesis Tissue Repair 6:20

71. Broide DH, Stachnick G, Castaneda D, Nayar J, Sriramarao $P$ (2001) Inhibition of eosinophilic inflammation in allergen-challenged TNF receptor $\mathrm{p} 55 / \mathrm{p} 75$-and TNF receptor p55-deficient mice. Am J Respir Cell Mol Biol 24:304-311

72. Di Giuseppe M, Gambelli F, Hoyle GW, Lungarella G, Studer SM, Richards T, Yousem S, McCurry K, Dauber J, Kaminski N et al (2009) Systemic inhibition of NF-kappaB activation protects from silicosis. PLoS One 4:e5689

73. Nam HS, Lee SY, Kim SJ, Kim JS, Kwon SS, Kim YK, Kim KH, Moon HS, Song JS, Park SH et al (2009) The soluble tumor necrosis factor-alpha receptor suppresses airway inflammation in a murine model of acute asthma. Yonsei Med J 50:569

74. Ye Q, Chen B, Tong Z, Nakamura S, Sarria R, Costabel U, Guzman J (2006) Thalidomide reduces IL-18, IL-8 and TNFalpha release from alveolar macrophages in interstitial lung disease. Eur Respir J 28:824-831

75. Câmara J, Jarai G (2010) Epithelial-mesenchymal transition in primary human bronchial epithelial cells is Smad-dependent and enhanced by fibronectin and TNF- $\alpha$. Fibrogenesis Tissue Repair 3:2

76. Piguet PF, Ribaux C, Karpuz V, Grau GE (1993) Expression and localization of tumor necrosis factor-alpha and its mRNA in idiopathic pulmonary fibrosis. Am J Clin Pathol 143:651-655

77. Kroner A, Greenhalgh AD, Zarruk JG, Passos Dos Santos R, Gaestel M, David S (2014) TNF and increased intracellular iron alter macrophage polarization to a detrimental M1 phenotype in the injured spinal cord. Neuron 83:1098-1116

78. Battegay EJ, Raines EW, Colbert T (1995) TNF-alpha stimulation of fibroblast proliferation. Dependence on platelet-derived growth factor (PDGF) secretion and alteration of PDGF receptor expression. J Immunol 154:6040-6047

79. Wynn TA, Vannella KM (2016) Macrophages in tissue repair, regeneration, and fibrosis. Immunity 44:450-462

80. Paulsson Y, Austgulen R, Hofsli E, Heldin C-H, Westermark B, Nissen-Meyer J (1989) Tumor necrosis factor-induced expression of platelet-derived growth factor A-chain messenger RNA in fibroblasts. Exp Cell Res 180:490-496

81. Caldwell AB, Cheng Z, Vargas JD, Birnbaum HA, Hoffmann A (2014) Network dynamics determine the autocrine and paracrine signaling functions of TNF. Genes Dev 28:2120-2133

82. Pękalski J, Zuk PJ, Kochańczyk M, Junkin M, Kellogg R, Tay S,

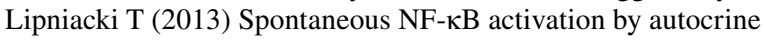
TNF $\alpha$ signaling: a computational analysis. PLoS One 8:e78887

83. Pilling D, Vakil V, Cox N, Gomer RH (2015) TNF- $\alpha$-stimulated fibroblasts secrete lumican to promote fibrocyte differentiation. Proc Natl Acad Sci 112:11929-11934

84. Epstein Shochet G, Brook E, Israeli-Shani L, Edelstein E, Shitrit D (2017) Fibroblast paracrine TNF- $\alpha$ signaling elevates integrin A5 expression in idiopathic pulmonary fibrosis (IPF). Respir Res 18:122

85. Pittet JF, Koh H, Fang X, Iles K, Christiaans S, Anjun N, Wagener BM, Park DW, Zmijewski JW, Matthay MA et al (2013) HMGB1 accelerates alveolar epithelial repair via an IL-1 $\beta$ - and 
$\alpha v \beta 6$ integrin-dependent activation of TGF- $\beta 1$. PLoS One 8:e63907

86. Gossart S, Cambon C, Orfila C (1996) Reactive oxygen intermediates as regulators of TNF-alpha production in rat lung inflammation induced by silica. J Immunol 156:1540-1548

87. Lin CC, Yang CC, Wang CY, Tseng HC, Pan CS, Hsiao LD, Yang CM (2016) NADPH oxidase/ROS-dependent VCAM-1 induction on TNF- $\alpha$-challenged human cardiac fibroblasts enhances monocyte adhesion. Front Pharmacol 6:310

88. Nakao A, Hasegawa Y, Tsuchiya Y, Shimokata K (1995) Expression of cell adhesion molecules in the lungs of patients with idiopathic pulmonary fibrosis. Chest 108:233-239

89. Agassandian M, Tedrow JR, Sembrat J, Kass DJ, Zhang Y, Goncharova EA, Kaminski N, Mallampalli RK, Vuga LJ (2015) VCAM- 1 is a TGF- $\beta 1$ inducible gene upregulated in idiopathic pulmonary fibrosis. Cell Signal 27:2467-2473

90. Blakney AK, Swartzlander MD, Bryant SJ (2012) The effects of substrate stiffness on the in vitro activation of macrophages and in vivo host response to poly (ethylene glycol)-based hydrogels. J Biomed Mater Res A 100:1375-1386

91. Irwin EF, Saha K, Rosenbluth M, Gamble LJ, Castner DG, Healy KE (2008) Modulus-dependent macrophage adhesion and behavior. J Biomater Sci Polym Ed 19:1363-1382

92. Nuovo GJ, Hagood JS, Magro CM, Chin N, Kapil R, Davis L, Marsh CB, Folcik VA (2012) The distribution of immunomodulatory cells in the lungs of patients with idiopathic pulmonary fibrosis. Mod Pathol 25:416-433

93. Mi S, Li Z, Yang HZ, Liu H, Wang JP, Ma YG, Wang XX, Liu HZ, Sun W, Hu ZW (2011) Blocking IL-17A promotes the resolution of pulmonary inflammation and fibrosis via TGF-beta1-dependent and -independent mechanisms. J Immunol 187:3003-3014

94. Ding W, Zhang X, Pan M, Zhao B, Chen C, Niu Z, Huang C, Li Y, Fan X, Ma Y et al (2015) Interleukin-17A promotes the formation of inflammation in the lung tissues of rats with pulmonary fibrosis. Exp Ther Med 10:491-497

95. Fabre T, Kared H, Friedman SL, Shoukry NH (2014) IL-17A enhances the expression of profibrotic genes through upregulation of the TGF- $\beta$ receptor on hepatic stellate cells in a JNKdependent manner. J Immunol 193:3925-3933

96. Griffin GK, Newton G, Tarrio ML, Bu DX, Maganto-Garcia E, Azcutia V, Alcaide P, Grabie N, Luscinskas FW, Croce KJ et al (2012) IL-17 and TNF- $\alpha$ sustain neutrophil recruitment during inflammation through synergistic effects on endothelial activation. J Immunol 188:6287-6299

97. Zrioual S, Ecochard R, Tournadre A, Lenief V, Cazalis MA, Miossec P (2009) Genome-wide comparison between IL-17Aand IL-17F-induced effects in human rheumatoid arthritis synoviocytes. J Immunol 182:3112-3120

98. Kurasawa K, Hirose K, Sano H, Endo H, Shinkai H, Nawata Y, Takabayashi K, Iwamoto I (2000) Increased interleukin-17 production in patients with systemic sclerosis. Arthritis Rheum 43:2455-2463

99. Brembilla N, Montanari E, Truchetet M-E, Raschi E, Meroni P, Chizzolini C (2013) Th17 cells favor inflammatory responses while inhibiting type I collagen deposition by dermal fibroblasts: differential effects in healthy and systemic sclerosis fibroblasts. Arthritis Res Ther 15:R151

100. Nakashima T, Jinnin M, Yamane K, Honda N, Kajihara I, Makino T, Masuguchi S, Fukushima S, Okamoto Y, Hasegawa $M$ et al (2012) Impaired IL-17 signaling pathway contributes to the increased collagen expression in scleroderma fibroblasts. J Immunol 188:3573-3583

101. Zhang Y, Choksi S, Chen K, Pobezinskaya Y, Linnoila I, Liu ZG (2013) ROS play a critical role in the differentiation of alternatively activated macrophages and the occurrence of tumorassociated macrophages. Cell Res 23:898-914

102. Huang H, Kim HJ, Chang EJ, Lee ZH, Hwang SJ, Kim HM, Lee Y, Kim HH (2009) IL-17 stimulates the proliferation and differentiation of human mesenchymal stem cells: implications for bone remodeling. Cell Death Differ 16:1332-1343

103. Kolb M, Margetts PJ, Anthony DC, Pitossi F, Gauldie J (2001) Transient expression of IL-1 $\beta$ induces acute lung injury and chronic repair leading to pulmonary fibrosis. J Clin Invest 107:1529-1536

104. Fan JM, Huang XR, Ng YY, Nikolic-Paterson DJ, Mu W, Atkins RC, Lan HY (2001) Interleukin-1 induces tubular epithelial-myofibroblast transdifferentiation through a transforming growth factor- $\beta 1$-dependent mechanism in vitro. Am J Kidney Dis 37:820-831

105. Ingram JL, Rice AB, Geisenhoffer K, Madtes DK, Bonner JC (2004) IL-13 and IL-1 $\beta$ promote lung fibroblast growth through coordinated up-regulation of PDGF-AA and PDGF-R $\alpha$. FASEB J 18:1132-1134

106. Bonner J, Lindroos P, Coin P, Badgett A, Osornio-Vargas A (1994) IL-1 $\beta$ and LPS mediate fibroblast hyperplasia through modulation of the PDGF receptor system. Cytokine 6:544

107. Meran S, Martin J, Luo DD, Steadman R, Phillips A (2013) Interleukin-1 $\beta$ induces hyaluronan and CD44-dependent cell protrusions that facilitate fibroblast-monocyte binding. Am J Pathol 182:2223-2240

108. Park MJ, Moon SJ, Lee EJ, Jung KA, Kim EK, Kim DS, Lee JH, Kwok SK, Min JK, Park SH et al (2018) IL-1-IL-17 signaling axis contributes to fibrosis and inflammation in two different murine models of systemic sclerosis. Front Immunol 9:1611

109. Shi Q, Lei Z, Cheng G, Li D, Wang Q, Luo S, Yang H, Jia H (2018) Mitochondrial ROS activate interleukin-1 $\beta$ expression in allergic rhinitis. Oncol Lett 16:3193-3200

110. Wilson MS, Madala SK, Ramalingam TR, Gochuico BR, Rosas IO, Cheever AW, Wynn TA (2010) Bleomycin and IL-1betamediated pulmonary fibrosis is IL-17A dependent. J Exp Med 207:535-552

111. Gasse P, Mary C, Guenon I, Noulin N, Charron S, SchnyderCandrian S, Schnyder B, Akira S, Quesniaux VFJ, Lagente V et al (2007) IL-1R1/MyD88 signaling and the inflammasome are essential in pulmonary inflammation and fibrosis in mice. J Clin Invest 117:3786-3799

112. Kolahian S, Fernandez IE, Eickelberg O, Hartl D (2016) Immune mechanisms in pulmonary fibrosis. Am J Respir Cell Mol Biol 55:309-322

113. Castillo EC, García-Rivas G, Torre-Amione G (2016) PT106 effects of B cells activation on cardiomyocytes and cardiac fibroblast function: Does Bregs activation have a cardioprotective role? Glob Heart 11:e144

114. Zhang X, Mosser DM (2008) Macrophage activation by endogenous danger signals. J Pathol 214:161-178

115. Lin X, Kong J, Wu Q, Yang Y, Ji P (2015) Effect of TLR4/ MyD88 signaling pathway on expression of IL- $1 \beta$ and TNF- $\alpha$ in synovial fibroblasts from temporomandibular joint exposed to lipopolysaccharide. Mediators Inflamm 2015:329405

116. Sha Y, Zmijewski J, Xu Z, Abraham E (2008) HMGB 1 develops enhanced proinflammatory activity by binding to cytokines. J Immunol 180:2531-2537

117. Park JS, Gamboni-Robertson F, He Q, Svetkauskaite D, Kim JY, Strassheim D, Sohn JW, Yamada S, Maruyama I, Banerjee A et al (2006) High mobility group box 1 protein interacts with multiple Toll-like receptors. Am J Physiol Cell Physiol 290:C917-C924 
118. Pan H, Ding E, Hu M, Lagoo AS, Datto MB, Lagoo-Deenadayalan SA (2010) SMAD4 is required for development of maximal endotoxin tolerance. J Immunol 184:5502-5509

119. Voll RE, Herrmann M, Roth EA, Stach C, Kalden JR, Girkontaite I (1997) Immunosuppressive effects of apoptotic cells. Nature 390:350-351

120. Fadok VA, Bratton DL, Konowal A, Freed PW, Westcott JY, Henson PM (1998) Macrophages that have ingested apoptotic cells in vitro inhibit proinflammatory cytokine production through autocrine/paracrine mechanisms involving TGF-beta, PGE2, and PAF. J Clin Invest 101:890-898

121. Huynh MLN, Fadok VA, Henson PM (2002) Phosphatidylserine-dependent ingestion of apoptotic cells promotes TGF-beta1 secretion and the resolution of inflammation. J Clin Invest 109:41-50

122. Lech M, Anders HJ (2013) Macrophages and fibrosis: how resident and infiltrating mononuclear phagocytes orchestrate all phases of tissue injury and repair. Biochim Biophys Acta 1832:989-997

123. Liu HZ, Yang HZ, Mi S, Cui B, Hua F, Hu ZW (2010) Toll like receptor 2 mediates bleomycin-induced acute lung injury, inflammation and fibrosis in mice. Yao Xue Xue Bao 45:976-986

124. West XZ, Malinin NL, Merkulova AA, Tischenko M, Kerr BA, Borden EC, Podrez EA, Salomon RG, Byzova TV (2010) Oxidative stress induces angiogenesis by activating TLR2 with novel endogenous ligands. Nature 467:972-976

125. Yang HZ, Cui B, Liu HZ, Chen ZR, Yan HM, Hua F, Hu ZW (2009) Targeting TLR2 attenuates pulmonary inflammation and fibrosis by reversion of suppressive immune microenvironment. J Immunol 182:692-702

126. Jiang D, Liang J, Fan J, Yu S, Chen S, Luo Y, Prestwich GD, Mascarenhas MM, Garg HG, Quinn DA et al (2005) Regulation of lung injury and repair by Toll-like receptors and hyaluronan. Nat Med 11:1173-1179

127. Yang K, Zhang XJ, Cao LJ, Liu XH, Liu ZH, Wang XQ, Chen QJ, Lu L, Shen WF, Liu Y (2014) Toll-like receptor 4 mediates inflammatory cytokine secretion in smooth muscle cells induced by oxidized low-density lipoprotein. PLoS One 9:e95935

128. Paun A, Fox J, Balloy V, Chignard M, Qureshi ST, Haston CK (2010) Combined Tlr2 and Tlr4 deficiency increases radiationinduced pulmonary fibrosis in mice. Int J Radiat Oncol Biol Phys 77:1198-1205

129. Kovach MA, Standiford TJ (2011) Toll like receptors in diseases of the lung. Int Immunopharmacol 11:1399-1406

130. Fang F, Ooka K, Sun X, Shah R, Bhattacharyya S, Wei J, Varga J (2013) A synthetic TLR3 ligand mitigates profibrotic fibroblast responses by inducing autocrine IFN signaling. J Immunol 191:2956-2966

131. Samara KD, Antoniou KM, Karagiannis K, Margaritopoulos G, Lasithiotaki I, Koutala E, Siafakas NM (2012) Expression profiles of Toll-like receptors in non-small cell lung cancer and idiopathic pulmonary fibrosis. Int J Oncol 40:1397-1404

132. Margaritopoulos GA, Antoniou KM, Karagiannis K, Samara KD, Lasithiotaki I, Vassalou E, Lymbouridou R, Koutala H, Siafakas NM (2010) Investigation of Toll-like receptors in the pathogenesis of fibrotic and granulomatous disorders: a bronchoalveolar lavage study. Fibrogenesis Tissue Repair 3:20

133. O'Dwyer DN, Armstrong ME, Trujillo G, Cooke G, Keane MP, Fallon PG, Simpson AJ, Millar AB, McGrath EE, Whyte MK et al (2013) The Toll-like receptor 3 L412F polymorphism and disease progression in idiopathic pulmonary fibrosis. Am J Respir Crit Care Med 188:1442-1450

134. Luckhardt TR, Coomes SM, Trujillo G, Stoolman JS, Vannella KM, Bhan U, Wilke CA, Moore TA, Toews GB, Hogaboam $\mathrm{C}$ et al (2011) TLR9-induced interferon $\beta$ is associated with protection from gammaherpesvirus-induced exacerbation of lung fibrosis. Fibrogenesis Tissue Repair 4:18

135. Lynch J, Nolan S, Slattery C, Feighery R, Ryan MP, McMorrow T (2010) High-mobility group box protein 1: a novel mediator of inflammatory-induced renal epithelial-mesenchymal transition. Am J Nephrol 32:590-602

136. Wang WK, Wang B, Lu QH, Zhang W, Qin WD, Liu XJ, Liu XQ, An FS, Zhang Y, Zhang MX (2014) Inhibition of high-mobility group box 1 improves myocardial fibrosis and dysfunction in diabetic cardiomyopathy. Int J Cardiol 172:202-212

137. Ge WS, Wu JX, Fan JG, Wang YJ, Chen YW (2011) Inhibition of high-mobility group box 1 expression by siRNA in rat hepatic stellate cells. World J Gastroenterol 17:4090-4098

138. He M, Kubo H, Ishizawa K, Hegab AE, Yamamoto Y, Yamamoto H, Yamaya M (2007) The role of the receptor for advanced glycation end-products in lung fibrosis. Am J Physiol Lung Cell Mol Physiol 293:L1427-L1436

139. Yang HZ, Wang JP, Mi S, Liu HZ, Cui B, Yan HM, Yan J, Li $\mathrm{Z}$, Liu H, Hua F et al (2012) TLR4 activity is required in the resolution of pulmonary inflammation and fibrosis after acute and chronic lung injury. Am J Pathol 180:275-292

140. Malaviya R, Sunil VR, Venosa A, Verissimo VL, Cervelli JA, Vayas KN, Hall L, Laskin JD, Laskin DL (2015) Attenuation of nitrogen mustard-induced pulmonary injury and fibrosis by anti-tumor necrosis factor- $\alpha$ antibody. Toxicol Sci 148:71-88

141. Sunil VR, Vayas KN, Cervelli JA, Malaviya R, Hall L, Massa CB, Gow AJ, Laskin JD, Laskin DL (2014) Pentoxifylline attenuates nitrogen mustard-induced acute lung injury, oxidative stress and inflammation. Exp Mol Pathol 97:89-98

142. Piguet PF, Vesin C (1994) Treatment by human recombinant soluble TNF receptor of pulmonary fibrosis induced by bleomycin or silica in mice. Eur Respir J 7:515-518

143. Raghu G, Brown KK, Costabel U, Cottin V, du Bois RM, Lasky JA, Thomeer M, Utz JP, Khandker RK, McDermott L et al (2008) Treatment of idiopathic pulmonary fibrosis with etanercept: an exploratory, placebo-controlled trial. Am J Respir Crit Care Med 178:948-955

144. Noble PW, Albera C, Bradford WZ, Costabel U, Glassberg MK, Kardatzke D, King TE Jr, Lancaster L, Sahn SA, Szwarcberg $\mathrm{J}$ et al (2011) Pirfenidone in patients with idiopathic pulmonary fibrosis (CAPACITY): two randomised trials. Lancet 377:1760-1769

145. Margaritopoulos GA, Vasarmidi E, Antoniou KM (2016) Pirfenidone in the treatment of idiopathic pulmonary fibrosis: an evidence-based review of its place in therapy. Core Evid 11:11-22

146. Guo J, Gu N, Chen J, Shi T, Zhou Y, Rong Y, Zhou T, Yang W, Cui X, Chen W (2013) Neutralization of interleukin-1 beta attenuates silica-induced lung inflammation and fibrosis in C57BL/6 mice. Arch Toxicol 87:1963-1973

147. Chen Y, Li C, Weng D, Song L, Tang W, Dai W, Yu Y, Liu F, Zhao M, Lu C et al (2014) Neutralization of interleukin-17A delays progression of silica-induced lung inflammation and fibrosis in C57BL/6 mice. Toxicol Appl Pharmacol 275:62-72

148. Aziz M, Brenner M, Wang P (2019) Extracellular CIRP (eCIRP) and inflammation. J Leukoc Biol 106:133-146

149. Qiang X, Yang WL, Wu R, Zhou M, Jacob A, Dong W, Kuncewitch M, Ji Y, Yang H, Wang H et al (2013) Cold-inducible RNA-binding protein (CIRP) triggers inflammatory responses in hemorrhagic shock and sepsis. Nat Med 19:1489-1495

150. Tsoutsou PG, Gourgoulianis KI, Petinaki E, Germenis A, Tsoutsou AG, Mpaka M, Efremidou S, Molyvdas PA (2006) Cytokine levels in the sera of patients with idiopathic pulmonary fibrosis. Respir Med 100:938-945

151. Saito F, Tasaka S, Inoue KI, Miyamoto K, Nakano Y, Ogawa Y, Yamada W, Shiraishi Y, Hasegawa N, Fujishima S et al (2008) 
Role of interleukin-6 in bleomycin-induced lung inflammatory changes in mice. Am J Respir Cell Mol Biol 38:566-571

152. Miller A, Ruwanpura S, McLeod L, Bardin P, Watkins N, Jenkins B (2012) Deregulated interleukin-6 signalling suppresses lung tumorigenesis in mice induced by the tobacco-specific carcinogen nicotine-derived nitrosamine ketone. D78. PATHWAYS AND MODELS OF LUNG ONCOGENESIS

153. Arras M, Louahed J, Heilier JF, Delos M, Brombacher F, Renauld JC, Lison D, Huaux F (2005) IL-9 protects against bleomycininduced lung injury: involvement of prostaglandins. Am J Pathol 166:107-115

154. Keane MP, Belperio JA, Burdick MD, Strieter RM (2001) IL-12 attenuates bleomycin-induced pulmonary fibrosis. Am J Physiol Lung Cell Mol Physiol 281:L92-L97

155. Passalacqua G, Mincarini M, Colombo D, Troisi G, Ferrari M, Bagnasco D, Balbi F, Riccio A, Canonica GW (2017) IL-13 and idiopathic pulmonary fibrosis: possible links and new therapeutic strategies. Pulm Pharmacol Ther 45:95-100

156. Dong Z, Lu X, Yang Y, Zhang T, Li Y, Chai Y, Lei W, Li C, Ai L, Tai W (2015) IL-27 alleviates the bleomycin-induced pulmonary fibrosis by regulating the Th17 cell differentiation. BMC Pulm Med 15:13

157. Le TTT, Karmouty-Quintana H, Melicoff E, Le TTT, Weng T, Chen NY, Pedroza M, Zhou Y, Davies J, Philip K et al (2014) Blockade of IL-6 Trans signaling attenuates pulmonary fibrosis. J Immunol 193:3755-3768

158. Johnson BZ, Stevenson AW, Prêle CM, Fear MW, Wood FM (2020) The role of IL-6 in skin fibrosis and cutaneous wound healing. Biomedicines 8. https://doi.org/10.3390/biomedicin es8050101

159. Kobayashi T, Tanaka K, Fujita T, Umezawa H, Amano H, Yoshioka K, Naito Y, Hatano M, Kimura S, Tatsumi K et al (2015) Bidirectional role of IL-6 signal in pathogenesis of lung fibrosis. Respir Res 16:99

160. Xu Y, Ikegami M, Wang Y, Matsuzaki Y, Whitsett JA (2007) Gene expression and biological processes influenced by deletion of Stat3 in pulmonary type II epithelial cells. BMC Genomics $8: 455$

161. She YX, Yu QY, Tang XX (2021) Role of interleukins in the pathogenesis of pulmonary fibrosis. Cell Death Discov 7:52

162. Liang J, Zhang Y, Xie T, Liu N, Chen H, Geng Y, Kurkciyan A, Mena JM, Stripp BR, Jiang D et al (2016) Hyaluronan and TLR4 promote surfactant-protein-C-positive alveolar progenitor cell renewal and prevent severe pulmonary fibrosis in mice. Nat Med 22:1285-1293
163. Huang E, Peng N, Xiao F, Hu D, Wang X, Lu L (2020) The roles of immune cells in the pathogenesis of fibrosis. Int J Mol Sci 21:5203

164. Leslie J, Millar BJM, del Carpio Pons A, Burgoyne RA, Frost JD, Barksby BS, Luli S, Scott J, John Simpson A, Gauldie J et al (2020) FPR-1 is an important regulator of neutrophil recruitment and a tissue-specific driver of pulmonary fibrosis. JCI Insight 5

165. Hasan SA, Eksteen B, Reid D, Paine HV, Alansary A, Johannson K, Gwozd C, Goring K-AR, Vo T, Proud D et al (2013) Role of IL-17A and neutrophils in fibrosis in experimental hypersensitivity pneumonitis. J Allergy Clin Immunol 131:1663-1673

166. Culley FJ (2009) Natural killer cells in infection and inflammation of the lung. Immunology 128:151-163

167. Vu TN, Chen X, Foda HD, Smaldone GC, Hasaneen NA (2019) Interferon- $\gamma$ enhances the antifibrotic effects of pirfenidone by attenuating IPF lung fibroblast activation and differentiation. Respir Res 20:206

168. Jiang D, Liang J, Hodge J, Lu B, Zhu Z, Yu S, Fan J, Gao Y, Yin $\mathrm{Z}$, Homer R et al (2004) Regulation of pulmonary fibrosis by chemokine receptor CXCR3. J Clin Invest 114:291-299

169. Strieter RM, Keane MP (2004) Innate immunity dictates cytokine polarization relevant to the development of pulmonary fibrosis. J Clin Invest 114:165-168

170. Bantsimba-Malanda C, Marchal-Sommé J, Goven D, Freynet O, Michel L, Crestani B, Soler P (2010) A role for dendritic cells in bleomycin-induced pulmonary fibrosis in mice? Am J Respir Crit Care Med 182:385-395

171. Tort Tarrés M, Aschenbrenner F, Maus R, Stolper J, Schuette L, Knudsen L, Lopez-Rodriguez E, Jonigk D, Kühnel MP, DeLuca $\mathrm{D}$ et al (2019) The FMS-like tyrosine kinase-3 ligand/lung dendritic cell axis contributes to regulation of pulmonary fibrosis. Thorax 74:947-957

172. Shin JS (2019) Unexpected role of dendritic cells in pulmonary fibrosis. Thorax 74:925-926

173. Wynn T, Barron L (2010) Macrophages: master regulators of inflammation and fibrosis. Semin Liver Dis 30:245-257

174. Pakshir P, Hinz B (2018) The big five in fibrosis: macrophages, myofibroblasts, matrix, mechanics, and miscommunication. Matrix Biol 68-69:81-93

175. Prasse A, Pechkovsky DV, Toews GB, Jungraithmayr W, Kollert F, Goldmann T, Vollmer E, Müller-Quernheim J, Zissel G (2006) A vicious circle of alveolar macrophages and fibroblasts perpetuates pulmonary fibrosis via CCL18. Am J Respir Crit Care Med 173:781-792 